\title{
AN INTERVIEW ABOUT SADDLE-MAKING, ONE OF THE TRADITION- AL HANDICRAFTS, IN BOSNIA AND HERZEGOVINA
}

\author{
Yusuf Ziya Sümbüllü̈ ${ }^{1}$ \\ Melinda Botalić
}

Faculty of arts and sciences, Adnan Menderes University

Faculty of Philosophy, University of Tuzla

Received: 29.06.2012.

UDC: 745/749:798.2(047.53)

Accepted: 28.08.2012.

\begin{abstract}
Handicraft products are of great value as material culture products since they have been used during definite times of a society. These products are significant because they will ensure cultural continuity between the past and future. Saaddle-making, a conventional handicraft, is one of these aforesaid culture transmitters of which realm of existence is getting narrow because of developing technology.
\end{abstract}

Key words: Culture, custom, handicraft, saddle

\section{INTRODUCTION}

Conventional handicrafts which are concrete culture products and have a culture transmission function are the name of one of the culture transmitters resulted from production relations which have been shaped by social life, and handicraft production form based on long-lasting knowledge, manners and experiences. Briefly, producing handicraft is to get manifactured and semi-manifactured products by processing certain raw materials with hand skills and even with simple hand kits (Aktan, 1989, p.4).

These handicraft products that come out as a result of publics consensus, their needs and expectations show long lasting and collective development. All in all, this product is a folk art product created in a very long period. Creative craftsmen produce successful samples with good parts by omitting degraded parts of their works. These samples are repeated by their colleguages and foremen, passed down, so it spreads (Aslier, 1979, p.5).

With a quite colourful diversity, conventional handicraft shaped by production style of the concerned society is the executer of a serious configurator with its effects to make life easier, significant and formalizing.

\section{${ }^{1}$ Correspodence to:}

Yusuf Ziya Sümbüllü, Faculty of arts and sciences, Adnan Menderes University Aydın, Turkey

E-mail: yzsumbullu@yahoo.com 


\section{EVALUATION}

Handicrafts have come out depending on natural conditions since the beginning of humanbeings. It gave the first examples so as to meet some needs of humanbeings. Then, these handicrafts differing in accord with natural conditions were qualified as traditional since it reflected feelings, artistic taste and cultural features of the society, and as a result it was exposed to an inevitable change and alteration against future. Naturally, change and alteration are the two indispensible dynamics. Even if this process is exposed to delay because of various reasons for some part of the society, it is inevitable to happen.

This differentation in production relations in the beginning gets so wide that it penetrates into the life's cells in time. This new production form that has incredible quick and effective effects on social dynamics under the general heading of globalization is effective on conventional production style as well as on social principles based on traditions and customs.

While this case forms new employment areas within the scope of elements stemming from nature of dominant production style and its content, it also commits decisiveness on existing sectoral equilibrium. In this reorganization process it can be said that the devil take the hindmost. In this sense, conventional handicrafts that try to challenge time with some little changes which won't spoil its spirit, and depending on traditions and cultural backgrounds of the concerned society is the first victim of industrial revolution. It is obvious that in the time of industrial era standstill, downturn and fall of these crafts based on manual labor have much more strong effect on cultural background of these crafts.

Examination and evaluation of conventional handicrafts which bear the stamp of general structure of their geography and sociocultural identity of this geography's society is of vital importance for revealing development process of the concerned society. Being aware of this importance will contribute in explaination of relation between past and present. Saddle-making is our subject among conventional handicrafts performed under the names of blacksmith, coppersmith, tinsmith, stabber, caner, boilersmith, felt maker, saddler, leather dealer, basket maker, quilt maker, tailor, silversmith, whitesmith and etc. This study that is done through this interview with Marinko Sego who is the last representative of Saddle -making, included in moribund occupations group in Bosnia and Herzegovina, Sarajevo Canton, will be presented to show the situation of concerned occupation and its experts. Before the interview it is appropriate to give some information about saddle naming this saddle-making occupation.

Saddle is put on the backs of horse, mule, donkey and camel all of which are pack animals. It is said that it was first used by Arabians and Persians and after passed to Turks. But it is clear from the findings of excavation and wall reliefs that many years before them Egypt, Mesopotamia and Anatolia nations knew how to carry loads with animals and so they put a vehicle on animal's back to carry loads. Horses and donkeys which are the most handmaid animals of people to carry loads have given way to motor vehicles, so this is seen the greatest factor for decrease in saddle-making ( http:// www.renkliweb.com/kultursanat).

\section{INTERVIEW}

\section{Hi, Could you please talk about yourself ?}

I am Marinko Šego from Sarajevo. My family had descended from Medjugorje. I graduated from Economy High School, but, I had to leave Economy Faculty due to some reasons. I am married father of two girls one of whom is teacher in Spain, another one is physical therapist. The reason why I left school was agedness of my father. During to early years of my infant life, I used to drop by this workstore frequently insomuch as I wrote the date of my first arrival on the wall.

\section{Can you give us information about your work- shop?}

This store dates back about 120 years. Before my father, The store was being run by the woman who is my grandmother as well. Later on, she handed over the store to my father. I have been working here for 40 years. Saddles here are for pack horses that worked in forests previously. Approximately 7-8 employees were working with me. But now, there is no worker except me since there is no great demand for saddle compared to before. 
Are you satisfied with your job?

I was satisfied materially and morally before. I purchased my house and car thanks to this occupation. However, I can't make enough money now.

Have you ever thought of quiting saddle-making?

Yes, even today I might quit saddle-making without hesitation as there is no longer customer. Furthermore, I am not able to get materials so easily.

What is the disadvantage of saddle-making?

The foremost problem is not to be able to get materials due to the high cost of it. I use materials from nature but then it s so hard, it looks like getting blood from a stone.

Did you pass your knowledge on your children?Is there anyone else advancing it after you?

The first owner of this store was a woman. That is why I always dreamt of my girls carrying on saddle-making. Unfortunatelly, they just know how to sew. What I am saying is that there is nobody who is going to continue this occupation after me.

Is there anyone else besides you that does the same job?

I am the only one who builds saddle in Sarajevo. I have the oldest store ranking from Baščarsija to Marin Dvor am the only Croation crafter in this region as well.Croation people don't carry on crafting any longer.

How did you decide on building saddlemaking?Mandatory or personal choice?

It sometimes occurs to me whether it was wise quiting Economy Faculty or not. I started saddle-making on my own accord. Early on, I had difficuty in building it but I learnt all details of occupation day by day. I feel no penitence for being saddle-maker. I love my job.

\section{Do you manufacture on order?}

In Yugoslavia times, I used to work on order. But it has been so long I took order for saddle from woodsmen from Montenegro, Sandzak and Macedonia.

Can you explain us shortly how to build saddle?

The first step is the cutting out of the saddle. The layout of the patterns is very important.I use a right and left hide that has been gauged for the same thickness. The owner of horse brings his horse to me so as to take its measurement It is similar like making shoes for people.

\section{Where do you get materials from?}

Previously,we used to get material from Slovenia in that it had the most qualified materials.Current materials in store are of old.I plan on shutting down the existing store and being retired. Before the war, My situation was in good working order but now I am in dire straits.

\section{How long does it take to build saddle?}

After all straps are separately cut out, all edges are attached each other.Building a saddle approximately takes 3 or 4 days depending on the competence.

Are there any different patterns of saddles?

Patterns are nearly the same, but measurements are various.

You have been building saddle for years. Do you keep an animal,namely horse?

I don't. I had dogs in the past. In addition, I educated police dogs in the course of war.

Have you ever designed a saddle?

I have not designed at all. But I had quite few catalogs that go back to Austria-Hungary period. With the help of these catalogs, I built several saddles. Some customers requested me to write their names on saddle. I fulfilled their desires by melting steel. I have just one sample and I am going to send it to my girl in Spain.

Is there any importance of colors of saddle? Which colors are popular among customers?

I build sadders according to customer $\mathrm{s}$ wishes. Mostly blue, green and red are preferred so that horses appeal to eyes.

How long does a saddle last?

Saddle consists of two patches one of which lasts 2 years. If the horse is used to carry loads, the saddle needs to be renewed every year.

Is this occupation your only source of income?

Yes,I have performed just saddle-making all through my life. Nothing else.

Do you have any book you recorded your works? Yes, I had 100 year old record book that dates back to Austria-Hungary period. I still keep this book which has seal of Austria-Hungarian Empire .We used to record all materials bought and basic works done in this book. Thus, Government used to determine taxes we had to pay. 
Do you have any memories you would like to share with us in your business life?

Yes I have. When I was little, a customer came into our store, leaving his harmonica. As soon as he left, someone else rushed in the store and asked me to buy him cigarette. Upon returning, there was neither man nor harmonica. Even now, I can easily remember his face.

\section{Thanks for sharing your time with us.}

Thank you too.

\section{RESULT}

Because of the ongoing process in mechanization of production and production style based on agriculture and devoid of vehicles transporting products, the art of saddle making defying the years is on the verge of losing.

Handicrafts play important role in representing the culture and traditions of any region. Handicrafts are substantial medium to preserve of rich traditional art, heritage and culture, traditional skills and talents which are associated with people's life style (Özkan, 2001, p.VI).

It is so significant to investigate, learn, protect the handicrafts of vital importance, and hand down the beauty of handicrafts to future generations not to forget humanity at the very moments of an era of high and information technology. The necessity of documenting the product and way of production is also pivotal for future generations. The disapperance of the indigenous knowledge in crafts and arts of saddle making may be lost if there is no one to pass it on to (Özkan, 2001, p. III).

All along the years, these kinds of arts and materials produced in parallel with it are part of society.There is no cultural value difference between a large carpet and a small stoneware since they both reflect the culture level, social life, artistic and the life style of society.Therefore, these goods are of value sourse in terms of contributing to national culture (Yavuz, 2006, p.13).
As we mentioned above,growth in commercial concern with the developing technology leads to attempts causing minumum cost and maximum goods. For this occasion, because of the fact that handicrafts do not meet needs of current time in the quality of satisfying supply and demand. Unfortunatelly, conventional handicrafts are about to lose (Kaya, 1974, pp. 100-107).

But financing these occupation experts through social and cultural funds in order to keep these arts exist symbolically can be useful for them to enter the process of tourism based and miniature product procedure.There could be no animals to put saddle but If a tourist comes to Bosnia and Herzegovina and buys a miniature saddle which is an example of Bosnia culture, this will contribute to the presentation of the country and producer as well as transferring culture to future generations.

Culture originates in a very long period like stalactites and dickites in caves but it can smash with careless acts. This is very important for national identity of nations that care about transferring.protecting and preserving their culture no matter what their cultures names and shapes are. Mission of conventional handicrafts and their occupation experts that help concerned society come todays situation wants support and fidelity from us.

\section{REFERENCES}

Aktan, O. (1989). El Sanatları [Crafts]. Ankara: Arsu Ofset. Aslıer, M, (1979). Sanatçı ve Halk Sanatı [Artist and Folk Art]. Türkiyemiz Dergisi 28. İstanbul.

Kaya, R. (1974). Türk Yazmacllık Sanatı, [The Art of Turkish Printed Scarves]. İstanbul: Çeltüt Matbaacılık.

Özkan, A. (2001). El Sanatlarının Araştırllmasinda Belgeleme Araci Olarak Fotoğrafin Yeri ve Önemi [The Study of The Importance of Photo Documentation as aTool Craft]. Dokuz Eylül Üniversitesi Sosyal Bilimler Enstitüsü, Yayımlanmamış YL Tezi, İzmir.

Yavuz, A. (2006). Cumhuriyet Döneminde Ankara Kalesi'ndeki Geleneksel El Sanatlarl, [Traditional Handcrafts, Ankara Castle in the Republican Period]. Gazi Üniversitesi Sosyal Bilimler Enstitüsü, Yayımlanmamış YL. Tezi, Ankara http://www.renkliweb.com/kultursanat/ 